Michał Boks a

(Polska Akademia Nauk Archiwum w Warszawie Oddział w Poznaniu)

Zuzanna Jaśkowska-Józefiak

(Uniwersytet im. Adama Mickiewicza w Poznaniu)

\title{
Listy Feliksa Nowowiejskiego (1877-1946) do Adama (1875-1965) i Marii (1877-1952) Wrzosków z 1936 r. (ze spuścizny Adama Wrzoska w Polskiej Akademii Nauk Archiwum w Warszawie Oddział w Poznaniu)
}

\section{Łaskawa Pani Dziekanowo,}

pod wrażeniem opowiadania o cudownym Obrazie M.B. ${ }^{1}$ w Dębkach ${ }^{2}$ udałem się nad morze i otóż powstał pierwszy szkic pieśni ${ }^{3}$, który załączam. Część I pieśni, pisana ołówkiem, po otrzymaniu słów przybierze dopiero wtedy ostateczną melodię - poeta znajdzie ostateczny wzór rytmu i rymu; część II stanowi refren, jednolity dla wszystkich zwrotek. Zdaje mi się, że melodia refrenu już się nie zmieni, a może i moje skromne słowa, naszkicowane pod natchnieniem cudownego Obrazu, będzie mógł poeta zużytkować. Proszę powiedzieć poecie treść zwrotek, które mają być dokomponowane; poeta powinien ściśle trzymać się rytmu t.j. akcentów także w 2. i następnych zwrotkach jak przy pierwszej zwrotce. Pod tym względem poezja musi przejść moją kontrolę.

Raz jeszcze dziękując za tak serdeczną opiekę lekarską ${ }^{4}$ łączę dla W. Szan. Państwa wyrazy głębokiego poważania Feliks Nowowiejski

Dębki, 30. lipca 1936.

${ }^{1}$ Obraz Matki Boskiej Królowej Korony Polskiej znajdował się w ołtarzu kaplicy w Dębkach, którego twórcą był Teodor Pliński. Ołtarz ten zniszczyli Niemcy w czasie okupacji hitlerowskiej.

${ }^{2}$ Dębki - osada letniskowa $\mathrm{w}$ województwie pomorskim, $\mathrm{w}$ powiecie puckim, $\mathrm{w}$ gminie Krokowa, położona u ujścia rzeki Piaśnicy do Morza Bałtyckiego.

${ }^{3}$ Pieśn do Matki Boskiej w Dębkach, nad morzem (op. 8, nr 7). Słowa ks. Tadeusza Karyłowskiego T.J. Muzyka Feliksa Nowowiejskiego, Poznań 1937.

${ }^{4}$ Ponieważ najbliższy lekarz przebywał w Krokowej, oddalonej o 11 km, Adam Wrzosek podczas pobytu w Dębkach udzielał porad lekarskich, nie pobierając za nie zapłaty od okolicznej ludności. Prawdopodobnie porad takich udzielał też letnikom. 
Wielce Szanowni Państwo,

miło mi przysłać W. Szan. Państwu moją „Pieśń do Matki Boskiej w Dębkach”, do słów Ks. T. Karyłowskiego T.J. ${ }^{5}$, wybitnego hymnologa, który ku mojemu zupełnemu zadowoleniu stworzył poezję według treści podanej mi przez Szan. Państwo. Cieszę się niezmiernie, że pieśń ta powstała w Dębkach, a to bezpośrednio po opowiadaniu mi przez Łask. Panią Dziekanową o łaskach i cudach Obrazu. Sam doznałem wewnętrznych łask Cudownego Obrazu i cieszyłbym się z całego serca, gdyby moja skromna pieśń przyczyniła się do rozpowszechnienia czci Obrazu M.B., Królowej Korony Polskiej w Dębkach nad morzem.

Raz jeszcze serdecznie dziękuję za łask. opiekę lekarską dla mnie i moich synów, którzy zdrowi zajechali do domu. Myśli moje ciągle błądzą po uroczych i cichych Dębkach...

Łączę serd. wyrazy dla Obojga Państwa i całej Rodziny oddany i wdzięczny

Feliks Nowowiejski

P.S. Pozwalam sobie przysłać jako druk dla muzeum kaszubskiego ${ }^{6} 5$ aryj z mej nowej powstającej drugiej opery (buffa) „Kaszuby" ${ }^{\prime 7}$ t teksty i melodie oryginalne kaszubskie.

(Odpis pieśni do M.B. w Dębkach - dla przyszłego druku - posiadam.)

Poznań, 20. sierpnia 1936

${ }^{5}$ Tadeusz Karyłowski (1882-1945) - polski jezuita, poeta i tłumacz (głównie utworów łacińskich). Zajmował się m.in. hymnologią i tłumaczył hymny kościelne.

${ }^{6}$ W okresie międzywojennym na terenie posesji Wrzosków w Dębkach funkcjonowało założone przez Adama Wrzoska etnograficzne Muzeum Kaszubskie. W latach 1926-1939 gromadził on zabytki kultury materialnej oraz okazy sztuki kaszubskiej pochodzące głównie z Żarnowca i jego okolic. W 1938 roku liczba zinwentaryzowanych eksponatów wynosiła 250. Na zbiory muzealne przeznaczono jeden duży pokój w domu Wrzosków oraz specjalnie w tym celu wybudowaną drewnianą chatę w stylu kaszubskim. W trakcie okupacji hitlerowskiej zbiory zostały zniszczone bądź rozgrabione. Ocalały jedynie: piec chlebowy, dwa żarna neolityczne oraz rzeźba madonny. W spuściźnie Adama Wrzoska przechowywanej w PAN Archiwum w Warszawie Oddział w Poznaniu zachowała się fotograficzna dokumentacja części eksponatów.

7 Opera komiczna Kaszuby op. 47, słowa ludowe, w szkicach. Poznań 1937, Warszawa 1947 (wyjątki). 
W. Szanowny i drogi Panie Profesorze!

Przepraszam, że dopiero dziś podziękuję za miły list i subwencję na druk układu na śpiew i organy (lub fort.) „Pieśni do M. B. w Dębkach, nad morzem”. Uwagi Pana Dziekana przesłałem poecie ${ }^{8}$, który w zupełności je uwzględnił. Proszę i do mego manuskryptu dopisać nowe poprawki dla jednolitości. Mam nadzieję, że tekst w obecnej redakcji zadowoli Pana Dziekana oraz Jego Małżonkę, w zupełności. Manuskrypt pójdzie zaraz do druku.

Miło mi donieść, że jeszcze w tym miesiącu, prawdopodobnie 23-25 b.m., będę nad Bałtykiem w Oliwie, gdzie proszono mnie na recital organowy na sławnych na całą Europę organach; mieszkać będę u pp. min. Papée ${ }^{9}$ w Gdańsku. Myśli moje pobiegną do niedalekich Dębek, Pańskiego Tusculum ${ }^{10}$.

Poznań, 4. IX 1936

Łączę wyrazy głębokiego szacunku dla Obojga Państwa oddany

Feliks Nowowiejski

Wilja 1936

\author{
Feliks Nowowiejski \\ Szambelan J.Ś. Papieża \\ Komandor Orderu Polonia Restituta
}

przesyła W. Szan. Panu Profesorowi i Jego przezacnej Rodzinie najserdeczniejsze życzenia Wesołych Świąt Bożego Narodzenia i Błogosławionego Nowego Roku: oby nasza wspólna pieśn do M.B. w Dębkach szerzyła kult Cudownego Obrazu i sprowadziła promienie łask na Pomorze i całą Polskę...

8 Tadeuszowi Karyłowskiemu.

${ }^{9}$ Kazimierz Papée (1889-1979) - polski dyplomata, Konsul Generalny RP w Królewcu (1929-1932), Komisarz Generalny RP w Wolnym Mieście Gdańsku (1932-1936), poseł RP w Czechosłowacji (1936-1939), ambasador RP przy Stolicy Apostolskiej (1939-1958).

${ }^{10}$ Miejscowość wypoczynkowa pod starożytnym Rzymem. 
Pieśń do Matki Boskiej w Dębkach, nad morzem

Jutrzenko morza, coś wieczne Stowo

Zrodzita w petnej dziewictwa chwale,

Wskrzeszonej Polski jasna Królowo,

Znijdź ponad modre Battyku fale!

Ave, ave Maria!

Nad polskim morzem dzierżąc straż,

Miej w stałej pieczy naród nasz!

Ave, ave Maria!

Ty, któraś wierne zawsze Kaszuby

Krzepiła w latach smutku i klęski,

Dziś wolny naród ratuj od zguby,

A w chwilach grozy wiedź w bój - zwycięski...!

Ave, ave Maria!

Nad polskim morzem dzierżąc straż,

Miej w stałej pieczy naród nasz!

Ave, ave Maria!

Ze szumem fali, co w brzeg uderza,

Do twego tronu głos korny leci:

„Z nadmorskich Dębek Polski wybrzeża

Strzeż, Gwiazdo morska, wśród burz zamieci!"

Ave, ave Maria!

Nad polskim morzem dzierżac straż,

Miej w stałej pieczy naród nasz!

Ave, ave Maria!

W sercach młodzieży zbudź miłość morza,

Do szczytnych ofiar nieć zapat święty,

Niech twoje ramie, o Matko boża,

Od przygód polskie broni okręty!

Ave, ave Maria!

Nad polskim morzem dzierżąc straż,

Miej w stałej pieczy naród nasz!

Ave, ave Maria! 
Grożące chmury odwróć z daleka,

Spraw, byśmy w wierze praojców trwali

I wiedź, gdzie niebios przystań nas czeka,

Królowo modrej Bałtyku fali!

\author{
Ave, ave Maria! \\ Nad polskim morzem dzierżac straż, \\ Miej w statej pieczy naród nasz! \\ Ave, ave Maria!
}

Publikowane powyżej listy pochodzą z 1936 roku i znajdują się w spuściźnie Adama Wrzoska, przechowywanej w Polskiej Akademii Nauk Archiwum w Warszawie Oddział w Poznaniu. Okazją do ich zaprezentowania jest ustanowienie przez Sejm Rzeczypospolitej Polskiej roku 2016 Rokiem Feliksa Nowowiejskiego. Dotyczą mniej znanego utworu kompozytora Pieśni do Matki Boskiej w Dębkach, nad morzem, do której słowa napisał Tadeusz Karyłowski. Pieśń ta poświęcona jest cudownemu obrazowi Matki Boskiej Królowej Korony Polskiej z kaplicy w Dębkach (pow. pucki), który Nowowiejski oglądał zapewne podczas swojego pobytu w tejże miejscowości. Przyjeżdżał tam na wakacyjny wypoczynek, a gościny udzielali mu prawdopodobnie Adam i Maria Wrzoskowie.

Adam Wrzosek uchodzi za jednego z odkrywców i popularyzatorów walorów przyrodniczych i turystycznych Dębek. Po I wojnie światowej była to mała, praktycznie nieznana kaszubska wioska rybacka przy ujściu rzeki Piaśnicy do Morza Bałtyckiego. W ciągu kilku lat przekształciła się w znane letnisko, popularne wśród poznańskich profesorów, harcerzy i studentów. W 1922 r. zaczęto tam parcelować grunty pod zabudowę domów letniskowych. W grudniu tegoż roku Wrzoskowie nabyli jedno z gospodarstw od Jana Greny. Również inni profesorowie Uniwersytetu Poznańskiego kupili parcele w Dębkach, m.in.: prof. Bronisław Niklewski (1879-1961, fizjolog roślin), prof. Antoni Stanisław Jurasz (1847-1923, otolaryngolog) i prof. Antoni Tomasz Jurasz (1882-1961, chirurg). Ponad to w 1935 r. Fundacja Nauka i Praca im. Rektora Uniwersytetu Poznańskiego Heliodora Święcickiego, której wicekuratorem był Adam Wrzosek, zbudowała w Dębkach duży dom wakacyjny dla młodzieży. Od 1923 r. latem organizowano w Dębkach obozy harcerskie. Harcerze mieszkali w dużych brezentowych namiotach (każdy na czterdzieści łóżek), będących własnością Fundacji Nauka i Praca. W 1935 r. Wrzoskowie przebudowali swój dom według projektu inż. architekta Tadeusza Hornunga z Poznania, stylizując go na ziemiański dworek. Przed przebudową miał on pod jednym dachem izby mieszkalne, stodołę i chlew. Po przebudowie na parterze urządzono dziewięć pokoi i dwie kuchnie, na poddaszu zaś pięć pokoi mansardowych. 
Z inicjatywy ks. Jakuba Kuklińskiego ze Zgromadzenia Zmartwychwstania Pana Naszego Jezusa Chrystusa (zmartwychwstańców) i Marii Wrzoskowej w stodole na terenie posesji Wrzosków w Dębkach powstała prowizoryczna kaplica, w której w miesiącach letnich kapłan zmartwychwstaniec odprawiał msze święte dla wczasowiczów i obozów harcerskich. Rektorami kaplicy byli na przemian ks. Jakub Kukliński (w latach 1930-1946) i ks. Bolesław Wośko (w latach 1930-1947). Z czasem Wrzoskowie ofiarowali poznańskiej placówce księży zmartwychwstańców część ziemi ze swej działki w Dębkach, na której ci rozpoczęli w $1932 \mathrm{r}$. budowę domu wypoczynkowego i kaplicy. Budowę domu i kaplicy z drzewa modrzewiowego projektu inż. architekta Tadeusza Hornunga, zrealizowaną przez firmę Szatkowskich z Chojnic, ukończono w 1935 r. W tym samym roku została zlikwidowana prowizoryczna kaplica w stodole Wrzosków ${ }^{11}$.

W 1999 r. posesja Wrzosków została przekazana Caritas Archidiecezji Poznańskiej. Mieści się tam obecnie Ośrodek Charytatywno-Wypoczynkowy „Gwiazda Morza”. Przylega do niej drewniany kościół pw. Matki Bożej Częstochowskiej (przedwojenna kaplica) z Ośrodkiem Rekolekcyjno-Wczasowym Zmartwychwstańców.

Autorem zaprezentowanych listów jest Feliks Nowowiejski - polski kompozytor, dyrygent, organista, chórmistrz, pedagog i organizator życia muzycznego. Urodził się 7 lutego 1877 r w Barczewie (Wartemborku) na Warmii, jako syn Franciszka Nowowiejskiego i Katarzyny z domu Falk. W latach 1887-1893 uczęszczał do szkoły muzycznej w Świętej Lipce, w której uczył się śpiewu, gry na skrzypcach, fortepianie, organach, wiolonczeli i waltorni oraz teorii. W latach 1893-1898 grał w orkiestrze II Pułku Grenadierów w Olsztynie. Od października 1898 do końca 1899 r. był organistą w kościele św. Jakuba w Olsztynie.

Edukację muzyczną kontynuował w: Konserwatorium Sterna w Berlinie (kwiecień-wrzesień 1898 r.), Szkole Muzyki Kościelnej w Ratyzbonie (styczeń-kwiecień 1900 r.), Akademickiej Wyższej Szkole Muzycznej przy Królewskiej Akademii Sztuk Pięknych w Berlinie (kwiecień 1900 - wrzesień 1902 r. i 1904 czerwiec 1906 r.) oraz w Królewskim Uniwersytecie im. Fryderyka Wilhelma w Berlinie (1901-1902). Od września 1902 r. od bywał osiemnastomiesięczną podróż artystyczną po Cesarstwie Niemieckim, Cesarstwie Austro-Węgierskim,

${ }^{11}$ Materiały Adama Wrzoska, Polska Akademia Nauk Archiwum w Warszawie Oddział w Poznaniu, sygn. P. III - 70; A. Wrzosek, Przedwojenne Muzeum Kaszubskie w Dębkach, "Lud” 1959, t. 44, s. 453-477; tegoż, Dębki pod Żarnowcem - przedwojenny ośrodek wypoczynkowy dla profesorów i studentów Uniwersytetu Poznańskiego, oprac. A. Marciniak, „Kronika Wielkopolski” 1996, nr 1(76), s. 91-96; tegoż, Kartka z historii Dębków, oprac. A. Magowska, „Acta Medicorum Polonorum" 2015, r. 5, z. 2, s. 91-96; Wyciąg z Księgi Pamiątkowej XX. Zmartwychwstańców w Dębkach, tamże, s. 97-98. 
Francji, Belgii, Włoszech i Tunezji (Kartaginie). Po ukończeniu w 1906 r. studiów muzycznych przez trzy lata przebywał w Berlinie z przerwami na koncerty, m.in. we Lwowie i Warszawie (kwiecień 1906 r.).

Od września 1909 r. do wybuchu I wojny światowej pełnił funkcję dyrektora artystycznego Towarzystwa Muzycznego w Krakowie. Podczas pobytu w Krakowie angażował się w działalność koncertową, pedagogiczną, kompozytorską i społeczną. Latem 1914 r. opuścił Kraków i udał się do Berlina. Służył tam w armii pruskiej, grając $\mathrm{w}$ berlińskiej orkiestrze garnizonowej. Do czynnego życia muzycznego powrócił w grudniu 1918 r., dając koncert w Berlinie.

Jesienią 1919 r. przeniósł się z Berlina do Polski. W 1920 r. udał się na tereny objęte akcją plebiscytową na Warmii i Mazurach, gdzie występował jako mówca i muzyk. Wykonywał koncerty propagandowe m.in. w Olsztynie, Kwidzynie i Barczewie.

Prawdopodobnie w listopadzie 1919 r. osiadł w Poznaniu. W stolicy Wielkopolski wpierw mieszkał w kamienicy przy ul. Stanisława Wyspiańskiego 12, a od 1929 r. we własnej willi przy Alei Wielkopolskiej 11.

W latach 1920-1927 pracował jako pedagog w Konserwatorium Poznańskim. Głównymi zajęciami, które prowadził, były gra na organach i nauka improwizacji. Ponadto wykładał przedmioty pomocnicze obowiązujące na wydziale muzyki kościelnej: kontrapunkt, harmonię, harmonizację chorału, instrumentację. Prowadził też orkiestrę szkolną. W 1927 r. zrezygnował z dalszej pracy pedagogicznej i poświęcił się głównie twórczości kompozytorskiej.

Podczas pobytu $\mathrm{w}$ Poznaniu zaangażował się $\mathrm{w}$ pracę $\mathrm{z}$ amatorskim ruchem muzycznym. Był założycielem i dyrygentem "Chóru Narodowego" (od 1920 r.), kierownikiem artystycznym chóru męskiego „Echo” (od 1922 r.), dyrygentem "Chóru Nauczycielskiego", dyrygentem Miejskiej Orkiestry Symfonicznej (1935-1939), działaczem Wielkopolskiego Związku Kół Śpiewaczych, prezesem Związku Chórów Kościelnych (od 1926 r.) członkiem komisji artystycznych oraz jurorem konkursów i zjazdów śpiewaczych. W maju 1929 r. został dyrygentem połączonych chórów na I Wszechsłowiańskim Zjeździe Śpiewaczym w Poznaniu. W okresie międzywojennym koncertował w Polsce oraz za granicą (m.in. w Londynie, Paryżu i Rzymie).

Okres okupacji hitlerowskiej spędził w Krakowie, gdzie początkowo kontynuował komponowanie utworów muzycznych. W grudniu $1941 \mathrm{r}$. doznał wylewu krwi do mózgu połączonego z prawostronnym paraliżem, który oznaczał kres jego pracy twórczej. W sierpniu 1945 r. powrócił do Poznania.

Był członkiem honorowym The Organ Music Society w Londynie (od 1931 r.). Otrzymał: I nagrodę stowarzyszenia The British Musician (1898), Nagrodę im. Giacomo Meyerbeera Prix de Rome za oratorium Powrót syna marnotrawnego i Uwerturę romantyczna (1902), Nagrodę im. Ludwiga van Beetho- 
vena w Bonn za uwerturę Swaty polskie (1903), Nagrodę im. Meyerbeera za Symfonię a-moll (później wycofaną) i Symfonię h-moll nr 1 (1904), I nagrodę na konkursie kompozytorskim we Lwowie za utwór Żałobny pochód Kościuszki na Wawel (1907), nagrodę za pieśń solową Zagasty już na konkursie kompozytorskim we Lwowie zorganizowanym z okazji setnej rocznicy urodzin Fryderyka Chopina (1910), I nagrodę na konkursie lwowskiego „Echa” za utwór chóralny Danae (1914), Państwową Nagrodę Muzyczną (1935), Krzyż Komandorski Orderu Polonia Restituta (1936), Odznakę Honorową Zjednoczenia Polskich Zespołów Śpiewaczych i Instrumentalnych (1936) oraz godność Szambelana Papieskiego (1935) za twórczość w dziedzinie muzyki kościelnej.

Był autorem: czterech symfonii orkiestrowych, uwertur koncertowych (m.in. Swaty polskie), poematów symfonicznych, Koncertu wiolonczelowego, Koncertu fortepianowego, trzech oratoriów (Powrót syna marnotrawnego, Quo vadis, Znalezienie Św. Krzyża), oper (m.in. Legenda Battyku i Kaszuby), baletów (m.in. Król Wichrów i Malowanki ludowe), kantat, mszy liturgicznych (m.in. Missa pro pace), dziewięciu symfonii organowych i czterech koncertów organowych, pieśni solowych z orkiestrą (m.in. cykl Róże dla Safo do słów Marii Pawlikowskiej-Jasnorzewskiej), pieśni solowych z fortepianem (m.in. Pod niebem Persji), utworów fortepianowych (m.in. Obrazki słowiańskie), utworów chóralnych (m.in. Teka biatowieska). Opracował liczne melodie ludowe i popularne, które wydał w zbiorach: Śpiewnik górnoślaski (1923), Nowy śpiewnik polski (1928), Zjednoczona Polska (1928), Śpiewnik Orła Białego (1934), Śpiewnik gwiazdkowy (1935), Śpiewnik morski (1935). Skomponował muzykę do Roty (do słów Marii Konopnickiej), której prawykonanie odbyło się podczas odsłonięcia Pomnika Grunwaldzkiego w Krakowie w 1910 r.

W 1911 r. ożenił się z pianistką Elżbietą Mironow-Mirocką, z którą miał pięcioro dzieci: Feliksa Marię (malarza i krytyka), Wandę, Kazimierza (1917-1972, pianistę i krytyka muzycznego), Adama (zm. 1976, inżyniera rolnika), Jana (introligatora). Zmarł 18 stycznia 1946 r. w Poznaniu. Został pochowany na Poznańskiej Skałce w Krypcie Zasłużonych Kościoła św. Wojciecha ${ }^{12}$.

Adresatami listów są Adam i Maria Wrzoskowie. Adam Wrzosek był lekarzem, profesorem Uniwersytetu Poznańskiego i Akademii Medycznej w Poznaniu. Urodził się 6 maja 1875 r. w Zagórzu pod Dąbrową Górniczą, jako syn Józefa i Pelagii ze Skibińskich. Uczęszczał do gimnazjów w Piotrkowie Trybunalskim i Łodzi. Studia z zakresu medycyny podejmował w Kijowie (1894-1897), Zurychu (1897) oraz w Berlinie (1897-1898), gdzie w 1898 r. uzy-

12 J. Boehm, Feliks Nowowiejski. Zarys biograficzny, Olsztyn 1968, s. 9-93; F. i K. Nowowiejscy, Dookota kompozytora. Wspomnienia o ojcu, Poznań 1971, s. 260-273; T. Przybylski, Nowowiejski Feliks (1877-1946), [w:] Polski Stownik Biograficzny, t. XXIII, z. 2, Wrocław-Warszawa-Kraków-Gdańsk 1978, s. 401-403. 
skał stopień naukowy doktora medycyny i chirurgii na podstawie dysertacji pt. O ostrym zapaleniu szpiku kostnego ze szczególnym uwzględnieniem zapalenia szpiku kostnego w wieku niemowlęcym. W tym samym roku otrzymał w Kijowie dyplom lekarza, który pozwalał na prowadzenie praktyki w zaborze rosyjskim. W 1899 r. pracował jako lekarz fabryczny w Zagórzu koło Dąbrowy Górniczej. W latach 1899-1901 odbył studia uzupełniające w Paryżu, Krakowie i Wiedniu.

W 1901 r. rozpoczął pracę w Zakładzie Patologii Ogólnej i Doświadczalnej na Wydziale Lekarskim Uniwersytetu Jagiellońskiego (UJ), gdzie był asystentem (1901-1906), docentem (1906-1910), profesorem nadzwyczajnym (1910) i zwyczajnym (1910-1913). W latach 1913-1918 pracował w Zakładzie Antropologii na Wydziale Filozoficznym UJ.

W 1902 r. otrzymał tytuł doktora wszech nauk lekarskich na UJ, który pozwalał mu na prowadzenie praktyki lekarskiej w zaborze austriackim. Habilitację z dziedziny patologii ogólnej i doświadczalnej uzyskał na UJ w 1906 r. na podstawie pracy pt. Znaczenie dróg oddechowych, jako wrót zakażenia w warunkach prawidłowych. W $1907 \mathrm{r}$. rozszerzono mu tamże habilitację na propedeutykę lekarską. W latach 1914-1918 był naczelnym lekarzem IV filii trzeciego Szpitala Fortecznego w Krakowie.

Po zakończeniu I wojny światowej był szefem Sekcji Naukowej Departamentu Sanitarnego Ministerstwa Spraw Wojskowych (1918-1919), kierownikiem Zakładu Patologii Ogólnej i Doświadczalnej na Uniwersytecie Warszawskim (listopad 1918 - luty 1919 r.) oraz szefem Sekcji Nauki i Szkół Akademickich w Ministerstwie Wyznań Religijnych i Oświecenia Publicznego (luty 1919 - listopad 1920 r.).

W 1920 r. przeniósł się na Uniwersytet Poznański (UP), gdzie organizował Wydział Lekarski, a w nim Zakład Historii i Filozofii Medycyny oraz Zakład Antropologii. Na UP był: dziekanem Wydziału Lekarskiego (1920-1922), profesorem zwyczajnym (1920), kierownikiem Zakładu Historii i Filozofii Medycyny (1920-1947), kierownikiem Zakładu Antropologii (1921-1946). W 1atach 1935-1939 kierował Zakładem Historii i Filozofii Medycyny na Uniwersytecie Stefana Batorego w Wilnie.

W czasie okupacji hitlerowskiej prowadził wykłady na Wydziale Lekarskim tajnego Uniwersytetu Ziem Zachodnich w Warszawie i Krakowie. W latach 1942-1944 pełnił funkcję dziekana Wydziału Lekarskiego, a następnie prorektora (1944-1945) tej uczelni.

Po wojnie powrócił do Poznania, gdzie odtworzył Zakład Historii i Filozofii Medycyny oraz Zakład Antropologii UP. W 1947 r. został przeniesiony przymusowo na emeryturę. W latach 1957-1960 był profesorem zwyczajnym w Katedrze Historii Medycyny Akademii Medycznej w Poznaniu.

Był członkiem czynnym Polskiej Akademii Umiejętności (PAU, od 1930 r.), sekretarzem Komisji Historii Nauk Matematyczno-Przyrodniczych Akademii 
Umiejętności i PAU (1913-1919), sekretarzem (1945-1948) i dyrektorem (1948-1950) Wydziału IV PAU, przewodniczącym Komisji Antropologicznej PAU (1946-1952); członkiem Akademii Nauk Lekarskich (od 1920 r.); prezesem (1925-1952) i członkiem honorowym (od 1959 r.) Polskiego Towarzystwa Antropologicznego; członkiem zwyczajnym (od 1910 r.) i honorowym (od 1912 r.) oraz przewodniczącym Komisji Lekarskiej (1923-1925 i 1929-1948) Poznańskiego Towarzystwa PrzyjaciółNauk; przewodniczącymPoznańskiego Towarzystwa Historii Medycyny i Nauk Przyrodniczych (1925-1948); członkiem honorowym Towarzystw Lekarskich - Częstochowskiego, Kaliskiego, Lubelskiego, Lwowskiego i Wileńskiego oraz w Druskiennikach.

Był redaktorem naczelnym "Archiwum Historii i Filozofii Medycyny" (1926-1952), „,Przeglądu Antropologicznego” (1926-1952) oraz „Nowin Lekarskich" (1927-1928).

Otrzymał doktoraty honoris causa: Uniwersytetu Stefana Batorego w Wilnie (1929), Akademii Medycznej w Poznaniu (1961) i Uniwersytetu Jagiellońskiego (1964). W 1909 r. przyznano mu nagrodę Akademii Umiejętności za książkę Jędrzej Śniadecki. Życiorys i rozbiór pism, t. 1-2 (1910), w 1913 r. zaś nagrodę Warszawskiego Towarzystwa Lekarskiego za książkę Ludwik Bierkowski. Monografia (1911). Został odznaczony Orderem Franciszka Józefa, Orderem Czerwonego Krzyża Austriackiego, Krzyżem Komandorskim Orderu Polonia Restituta (1923) i Krzyżem Komandorskim Orderu Odrodzenia Polski (1958). Jego dorobek naukowy obejmuje ponad 450 pozycji z zakresu historii medycyny, patologii ogólnej i doświadczalnej, bakteriologii, a także historii kultury polskiej, antropologii i etnografii. Zmarł w Poznaniu 26 lutego $1965 \mathrm{r}^{13}$

Maria Wrzosek urodziła się 23 stycznia 1877 r. w Kijowie, jako córka Mikołaja Dąbrowskiego i Marii z domu Witwickiej. W latach 1897-1902 studiowała medycynę na Uniwersytecie $\mathrm{w}$ Zurychu. W trakcie studiów w 1900 r. - poślubiła Adama Wrzoska, którego poznała kilka lat wcześniej w Kijowie. W tym samym roku przedwcześnie urodziła dwie córki, z których tylko jedna - Ludmiła - utrzymała się przy życiu. Po ukończeniu studiów, jako żona profesora akademickiego, poświęciła się rodzinie. Zmarła 21 czerwca 1952 r. w Poznaniu. Została pochowana w grobowcu rodzinnym na Cmentarzu Junikowskim w Poznaniu (razem z mężem i córką Ludmiłą Krakowiecką) ${ }^{14}$.

${ }^{13}$ L. Krakowiecka, Adam Wrzosek (6 V 1875 - 26 II 1965), „Kronika Miasta Poznania” 1966, r. 34, nr 2, s. 102-104; Wielkopolski Stownik Biograficzny, Warszawa-Poznań 1981, s. 848-849; Biogramy uczonych polskich, cz. 6, Nauki medyczne, z. 2, M-Z, oprac. A. Śródka, Wrocław-Warszawa-Kraków 1991, s. 312-318; tegoż, Uczeni polscy XIX-XX stulecia, t. 4, Warszawa 1998, s. 543-546; Z. Maćkowiak, M. Musielak, Adam Wrzosek. Życie i działalność, Poznań 2000.

${ }^{14}$ Materiały Adama Wrzoska, Polska Akademia Nauk Archiwum w Warszawie Oddział w Poznaniu, sygn. P. III - 70. 


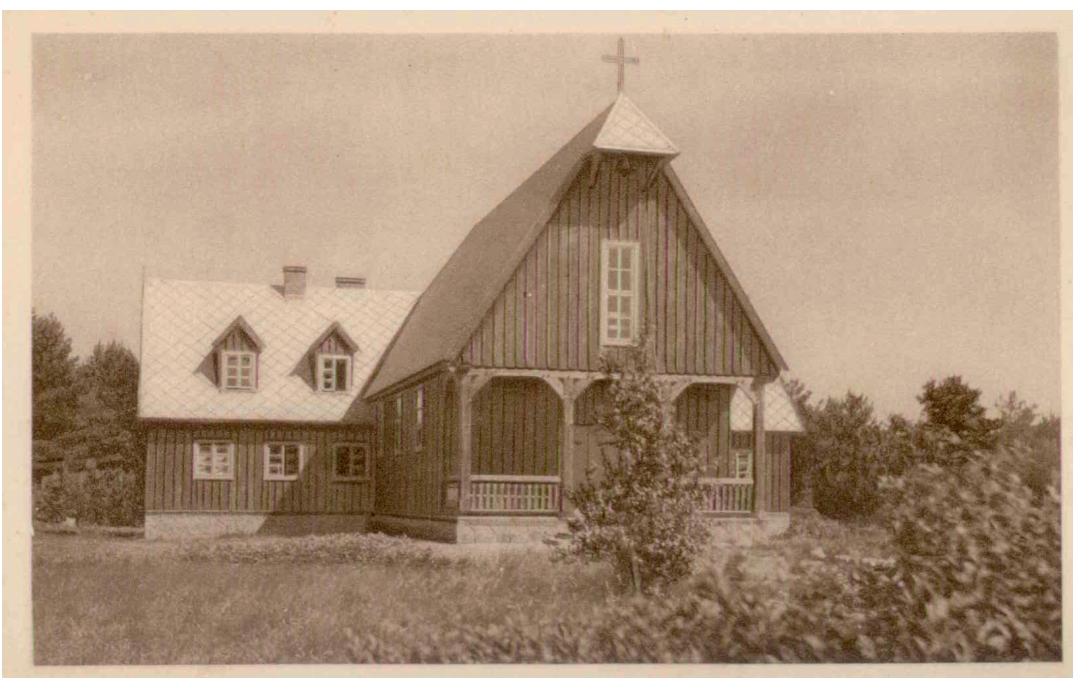

Il. 1. Dębki. Kaplica (karta pocztowa) Źródło: spuścizna Adama Wrzoska (sygnatura P.III-70) w zbiorach Polskiej Akademii Nauk Archiwum w Warszawie Oddział w Poznaniu.

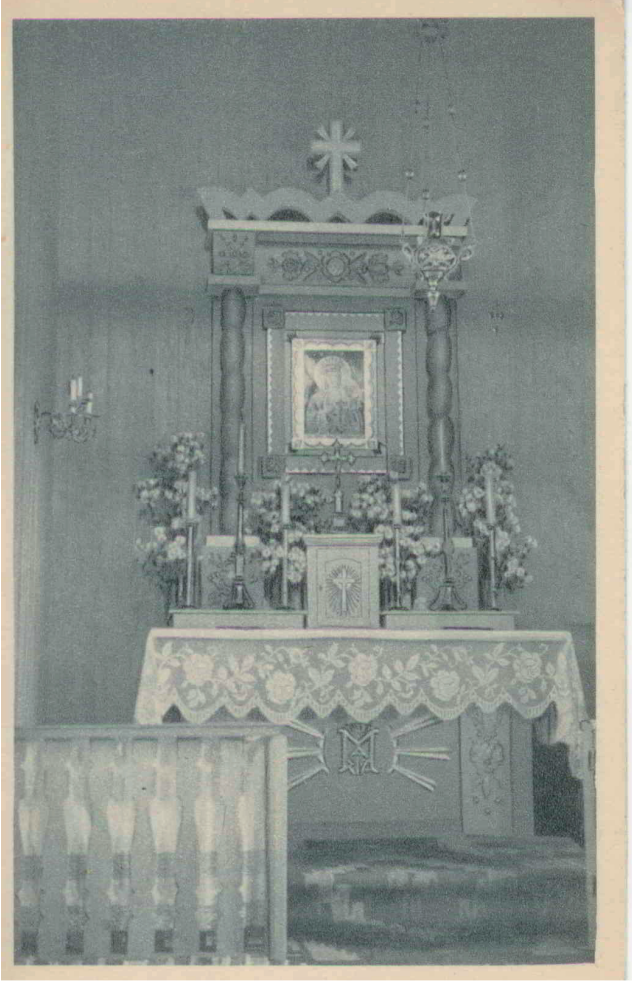

Il. 2. Dębki. Ołtarz w kaplicy (karta pocztowa)

Źródło: jw. 


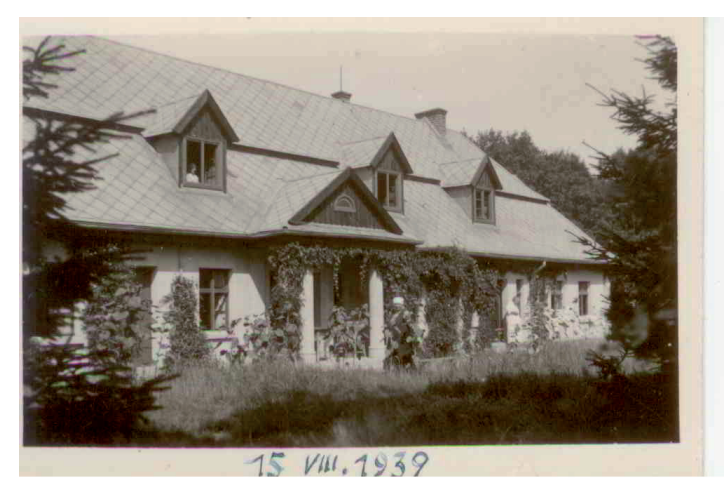

Il. 3. Dworek Wrzosków w Dębkach (zdjęcie) Źródło: jw.

Michał Boksa, Zuzanna Jaśkowska-Józefiak

$$
\begin{gathered}
\text { Listy Feliksa Nowowiejskiego (1877-1946) } \\
\text { do Adama (1875-1965) i Marii (1877-1952) Wrzosków z } 1936 \text { r. } \\
\text { (ze spuścizny Adama Wrzoska w Polskiej Akademii Nauk } \\
\text { Archiwum w Warszawie Oddział w Poznaniu) }
\end{gathered}
$$

Streszczenie

Tekst zawiera przedruk korespondencji kompozytora Feliksa Nowowiejskiego z prof. Adamem Wrzoskiem i jego żoną Marią z roku 1936, przechowywanej w zbiorach Polskiej Akademii Nauk w Warszawie Oddział w Poznaniu. Tematyka listów dotyczy mało znanej „Pieśni do Matki Boskiej w Dębkach, nad morzem". Utwór skomponowano ku czci cudownego obrazu Matki Boskiej Królowej Korony Polskiej znajdującego się w kaplicy w Dębkach (pow. pucki), który F. Nowowiejski oglądał zapewne podczas pobytu wakacyjnego w tejże miejscowości.

\title{
Letters of Feliks Nowowiejski (1877-1946) to Adam (1875-1965) and Maria (1877-1952) Wrzosek from 1936 (from the heritage of Adam Wrzosek in the Polish Academy of Sciences in Warsaw, Poznań branch)
}

\begin{abstract}
The text includes a reprint of letters exchanged in 1936 between composer Feliks Nowowiejski, and professor Adam Wrzosek and his wife, Maria, included in the collection of the Polish Academy of Sciences in Warsaw, Poznań branch. The letters discuss "The song to Our Lady of Dębki by the sea", a little-known work of the composer. It was composed in honor of the miraculous painting of Our Lady, Queen of the Crown of Poland. The painting can be admired in the chapel in Dębki (Puck county), and Feliks Nowowiejski had probably seen it while spending his holidays in this particular resort.
\end{abstract}

